\title{
'The Event', 'the Archive', and 'Realms That Are Yet to Come' in Paul Scott's The Raj Quartet
}

\author{
Areej M.J. Al-Khafaji \\ Department of English, College of Arts, Al-Qadisiya University, Iraq
}

\begin{abstract}
Two enigmas remain unsolved in the four novels of Paul Scott's the Raj Quartet: the engineer/performer of Daphne's rape which opens the whole tale and the engineer/performer of Merrick's murder which closes it. Both are ritualistic events engineered/performed patiently and carefully almost with the same scenario which gives confidence that the second is a vengeful sequence of the first. If we interrogate the Quartet in the light of postmodern discourses, some bizarre results can be found concerning these two crimes. Dealing with the Quartet as a detective story, reversing the narrative linear structure, and following the discourses of the event, the archive, and realms that are yet to come/the posthuman, reveal the scandalous superiority of the Eastern subject over the Western object which Scott dares not to say or avoids saying directly in the long course of his novels.
\end{abstract} West

Index Terms - archive, East, event, postmodernism, the Raj,

\section{INTRODUCTION}

"This is the story of a rape, of the events that led up to it and followed it".

Paul Scott (JC, 1).1

A poststructuralist reading/re-writing of Paul Scott's The Raj Quartet requires a re-consideration of the pragmatic significance of this declaration, of the dynamics of this 'informative' utterance, which is meant to be 'performative'. ${ }^{2}$ It has promising effects on the referent, or the story itself as being 'story of a rape' because it has been declared as such by an omniscient narrator who claims absolute authority to make such a statement. The omniscience of Scott's narrator makes him the focal character in the novels though the other characters are not deprived of re-presenting themselves through various, sometimes intriguing, narrational techniques. His ubiquity, invisibility, or absent presence in the Raj world is exactly as a persona who is raised high above the others with authentic perfection of knowledge, as an infallible god. The addressee (reader/observer of the system) is "immediately placed within the new context created by the utterance", which is intended to be out of 'discussion or verification'. However, in spite of the wide range of narratives around the 'rape', it remains an 'unpresentable' event, it is put into play without concern for the phenomenological metaphysics of presence of its performers, resisting the pre-existent meaning for the event which maintains its different/deferral quality every time it is re-produced or iterated. $^{3}$ This coincides with the problematic of acquiring knowledge in the postmodern era which engenders the "contemporary tradition of narrative analysis", and "contemporary philosophical research". 4 Epistemologically speaking, cognition does not dissent from the 'mirror theory of knowledge', or the representational mode which assumes, in narrative realism, the "reproduction, for subjectivity, of an objectivity that lies outside it", breaking with the qualities of truth, adequacy and accuracy to the original forms. This "shift.

from a representational to a nonrepresentational practice" creates a cognitive crisis, which results from non/postreferential hypothesis. Hence, the narrative develops from linear or sequential pattern into spiral pattern. This enables us to read/re-write the main story of The Raj Quartet from its margins, deciphering an unusual scenario which sheds light on the principles of the new world order emerged in the post-WWII and functions in today's politics and poetics.

\section{The EVEnt: Who SILENCES THE RAPE?}

"This ideal text ... has no beginning; it is reversible, we gain access to it by several entrances, none of which can be authoritatively declared to be the main one."

Barthes' $S / Z^{4}$

The mystery of what had happened to Daphne Manners and who raped her in the darkness of the Bibighar Gardens remains unsolved although the readers are well-kept watching traces of that particular night in August 9th, 1942-the beginning of Gandhi's Quit India Movement which ended up in 1947 with India's Independence as well as its division into present-day India and Pakistan. In that same night, the riotous mob had attacked Edwina Crain, an old British operator of the Mission schools, killed $\mathrm{Mr}$ Chaudhuri, the Indian teacher who accompanied her, and threatened "to show her what women

Journal of University of Human Development

Volume 5 No. 3(2019); DOI: 10.21928/juhd.v5n3y2019.pp23-27

Regular research paper: Published 8 July 2019

Corresponding author's e-mail: dr_areej1972@yahoo.com

Copyright (C 2019 Areej M.J. Al-Khafaji. This is an open access article distributed under the Creative Commons Attribution License

(CC BY-NC-ND 4.0) 
were for and what men could do" (JC, 64). Usually, these two incidents are read in the light of each other so that the gaps in the Daphne-case are filled up from the detailed description of the Edwina-case, thinking superficially that Daphne was 'gangraped' by mysterious Indian 'hoodlums'. The 'rape' becomes a signifier of contemporary understanding of race, gender, and sexuality, or how the body is represented in the text. The two attacks are read according to a 'trope' of thought that spread in British India after the 1857 mutiny in which 'white women' were situated "in mortal physical and sexual danger at the hands of barbaric and lustful Indian men". ${ }^{6}$ Yet, the 'rape' refers to more than this if we know that the two cases were investigated by the same Superintendent of the Police, Ronald Merrick who had already proposed to Daphne but she refused to marry him and preferred to be in love with a handsome poor Indian young man who was raised and educated in Britain until the age of eighteen. Her lover's conceptual identity is instantiated by his double name, Harry/Hari according to the two regions (Britain/India) where he functions. Realising that the 'rape' is a highly effectuated event on the ego of the British bourgeois, Merrick 'engineered' certain evidences to accuse Harry/Hari and seven other educated Indians with the rape of Daphne Manners. He wanted to say the event of the rape in his own way without taking into consideration that the event is different from saying the event.

According to Derrida, the event implies 'surprise', 'exposure', or 'the unanticipatable'. If there is an event, "it must never be something that is predicted or planned, or even really decided upon". ${ }^{7}$ The event is also "what comes, what happens [arrive].... the event as other or as the coming of the other". It seems to be "impossible before it occurs [arriver]", but when repeated, iterated, said, or interpreted, it returns spectrally. The event itself is the revenant arrived who functions "as the ghosts of the dead coming back". ${ }^{8}$ This definition of the 'rape' as an event is true if we follow the plot of the Raj Quartet in a linear order. However, as we revise the events, we collect certain details about the characters involved in the rape, specially Merrick who, as a Machiavellian patient competitor, 'engineered' traps for his 'chosen' victims, using Indians as tools to deceive his enemies. For Deleuze, the event should not be confused with the 'accident'; 9 hence, although the 'rape' functions as (in)visible as a spectre or a ghost haunting Scott's novel from the beginning to the end, it did not happen accidently. But why the novel does not show a description of what had happened in the rape scene? Why did the witnesses of the rape prevent saying it openly, or 'is saying the event possible?' There are at least two ways of 'saying the event': first, by informative speech, or saying that means "speaking ... enunciating, referring to, naming, describing, imparting knowledge, informing". Indeed, "saying the event is also saying what happens, trying to say what is presently, what comes to pass presently, saying what is, what happens, what occurs, what comes to pass". This is also a "saying that is close to knowledge and information, to the enunciation that says something about something". This saying of the 'rape' event has not happened in the four novels of The Raj Quartet, "this saying of the event is always somewhat problematical because the structure of saying is such that it always comes after the event and it is bound to a measure of generality, iterability, and repeatability, it always misses the singularity of the event". For Lyotard, saying the event involves a play of tricks, or "an essentially conflictual relationship between tricksters" who play on the signifiers in order to produce a special narrative. ${ }^{10}$ Merrick tries to say his version of the rape event, his narrative is an essential part of this tricks industry that results in a 'legitimation crisis' in the storytelling. He creates a 'Canonical Narrative', a saying "that does, that enacts". ${ }^{11}$ This saying that makes the event while feigning simply to state, describe, and relate it, constitutes an immense field of analysis and criticism. His utterance "does not say the event, it makes it, it constitutes the event. It's a speech-event, a saying-event". His strategy confirms that "event-making is covertly being substituted for event-saying". He leads the British bourgeois to believe in "modes of speaking that consist not in informing, reporting, relating, describing, or noting but in making something happen through speech". So his "informative speech becomes itself performative speech, or saying the event that consists in making the event, in making it happen, and to look at the impossibility lodged in this possibility". ${ }^{12}$

However, Daphne sabotages Merrick's plans to confirm his own narrative of her rape by showing inconsistencies in his canonical version. She says that there is a possibility of her rapists being British subjects who painted their faces and pretended to be Indians. She shows that "there is a saying of the event, of what happened, that produces a transformation". She claims that Merrick might have produced (an)other event and his narrative is not simply a saying of knowledge: "Every time that saying the event exceeds this dimension of information, knowledge, and cognition, it enters the 'night of non-knowing', something that is not merely ignorance, but that no longer pertains to the realm of knowledge". However, as a nonknowing narrator, Merrick did not express lack, ignorance, or non-science, but he presented a saying the event that "produces the event beyond the confines of knowledge.... where, ultimately, the possibility that such and such an event will happen appears impossible". ${ }^{12}$ Although saying the event of the 'rape' is possible-im-possibility, we can gather the parts of the jigsaw which are scattered in the four parts of The Quartet, reading it as a detective story by investigating its archives.

\section{THE ARCHIVE RECORDS THE EVENT AND RE-PRODUCES IT:}

The archive "is the general system of the formation and transformation of statements". Foucault,

The Archaeology of Knowledge $e^{13}$

The archive is a structured system of knowledge, or a "residual material left in the postcolony". ${ }^{14}$ Hence, the British authority in Scott's novels was very careful of what is to be written of its history and what should be left oral, or subjected to speculation and uncertainty. The events of the novels are structured in two types of order: sequential and jussive, or 'commencement' and 'commandment': events according to nature and events according to the law. This means that the events are first set to go naturally, then they are detoured by men and gods, or men as gods who command the archives to be appropriated in a certain way. In this sense, British and Indian men are turned into things re-written according to "the archons, those who commanded". ${ }^{16}$ The citizens who thus held and signified 
political power are considered to possess the right to make or to represent the law. They are also accorded the hermeneutic right and competence of the official documents. They have the power to interpret the archives.

The central archons who were entrusted to guard the rape's official documents were Rowan and Perron, two upper middle class gentlemen who graduated from Chillingborough, a significant institution providing the Raj with efficient administrators and militants. It provided also the line of thought, the point of view of the British upper middle class, the White. The White are those "whose voices are listened to at international gatherings". ${ }^{17}$ The modern world organisation is built on how some people "look like, where they come from, how they speak, even what they eat, that is racial judgements". All the sophisticated figures in Scott's novels passed through the boarding school of Chillingborough, including an ill-fated Indian lad who studied there until the age of eighteen and was intended by his father to acquire the language, values, and culture of the British bourgeoisie. Bankrupt, the father committed suicide and left his son penniless so he was forced to come back into an India that he did not know and did not know how to speak its language. The young man ironically held two names that denote the two men inside him: the British Harry Coomer, and the Indian, Hari Kumar. The psychic division inside Harry/Hari, who was raised to be British and found himself suddenly alone on the shores of India that he did not know, was given a racial and cultural dimension, he became 'the permanent loose end', "too English for the Indians, too Indian for the British" (DS, 550). For the Indians, he meets all the prerequisites of the question of the foreigner: "someone who does not speak like the rest, someone who speaks an odd sort of language".$^{18}$ And, for the British, his colour constructs his nonBritish identity that prevents him from being a white citizen. Yet, the brown skin could not hide the white mentality, Harry thinks in English, the only language that he learnt. The superstructures of English Language naturalized, ordered, and regulated his "Western social space and consciousness". ${ }^{19} \mathrm{He}$ acquired the 'signifying consciousness' of the British upper middle class, their 'mythical speech' which is presupposed by history that "converts reality into speech". ${ }^{20} \mathrm{He}$ consumed the bourgeois ideology, and reproduced his own "forms of speech, consciousness, morality, values, law, family life, and personal relations". These potentialities help him to survive as the most self-conscious figure of The Quartet up to its very end. The challenge that the readers of the novels should hold is that although seen as non-white, Harry functions as a white subject in both white and non-white worlds. The 'systems of simulacra', ${ }^{21}$ in which the different relates to its other through; for instance, 'virtual' difference between white and non-white is not valid to Harri/Harry who is a unique case. This paper argues that he is the sole engineer of all the white-like schemes that are deliberately silenced in The Towers of Silence and A Division of the Spoils; such as throwing the rape traces everywhere and the ultimate murder of Merrick.

The other challenge which should be handled is the division between the documentary/historic facts and the fictive/imaginative story. The Raj Quartet transcends "the category of fiction by providing us with a truthful account of history; and ... this history is very well balanced since the Quartets deals with the empire through the lens of anti- imperialism". ${ }^{22}$ The Quartet is a 'fictionalized history', 'it engages in an active redefinition of the 'imperial] past'. Both excolonizer and ex-colonized "need to reinterpret the past in a manner that is most conductive to their future goals". It is quite challenging to distinguish the real from unreal events, leaving a schizophrenic mood of perception, or better an uncanny which does not facilitate reading the focal event of the rape. The novel maintains both the line of fictitious characters who evolve around the most effectuated event of the 'rape', and the factious line of the documentary or historical survey of the last five years in the Raj life. This makes The Raj Quartet, according to Allen Boyer, "a historical essay, an exploration and interpretation of history, in novel form". ${ }^{23}$ However, instead of reading a straightforward narratives of progress in the historical record, Scott approaches the main issues of his novels in terms of Foucault's archaeological "working through the historical archives ... to bring to light the discursive formations and events" of a certain period. Definitely, the 'historical description' cannot be evidently used interchangeably with 'literary analysis', which now focuses on "the particular structure of a given reuvre, book, or text"'. ${ }^{24}$ We should follow a method of analysing what is 'said', seeking "the things that were said not in them, but in the system of discursivity, in the enunciative possibilities and impossibilities that it lays down". ${ }^{25}$ Hence, new hermeneutics/meaning will be attained by deconstructing the records to re-produce the scenario of the main events in Paul Scott's The Raj Quartet, or showing how the archives were (re)written by the archiveskeepers/interpreters.

One of the chief representations of the archons is the university as "a prestigious, national and regional institution, ... housing historical material [that] becomes synonymous with an austere and strictly administered environment, preserved for the education of the elite and privileged". The university has an access to the nation's history due to its claim of a discipline and correct behaviour at once associated with hard work and intellectual endeavour. As an academic institution, "the university appears as the ultimate preserve of knowledge", says Foucault. The university as an authoritative institution of knowledge represents a safe shelter to the historical records of the (post)colony. It also stands in a stark contrast to the popularly misinterpreted behaviour associated with street culture, everyday life experiences and the goings on enacted as popular culture. In this context, the university authenticates history and the archives, relegates them to a secure location, sets them aside from public view. Strict administrative processes and protocol were "normalised into the process of conservation, as if proving and sustaining the maturity of the nation state". So the only characters who are trusted with the archives are the postgraduates: Rowan and Mohammed Ali Qasim, being officially able to (re)write or appropriate the British and Indian archives in a legitimate way.

Generally speaking, the archives neglect the 'Unknown Indian' as well as the Unknown British. That is why, when Barbie gave to Merrick the old coronation photograph of Queen Victoria as the Empress of India, the photograph which begins in the possession of Edwina Craine and ends in the hands of Susan's child Edward, she reminds him of this fact because they all belong to the same category, the Unknown Citizens, who 
commence the natural and the historical, but fell out of commandment and authority. Their stories are forgotten, not mentioned in the archives. Not only the Indian archives are rewritten, but the British archives too, a fact that makes the spirit of Merrick unrestful in his grave. His murder is removed totally from the archives, specially that he was a homosexual attracted to Indian Boys only. We have never found him attracted to British boys, on the contrary, we noticed that British men, such as Teddie Benham were sexually attracted to him. What is also removed from the official archives is the fact that Merrick used Indian agents secretly to perform his dirty work. The Red Shadow helped him to manipulate the simple-minded homosexual secretary of Susan Layton's psychiatrist, possess her psychological records, and use them to marry her. This proves Perron's theory of 'Merrick's chosen People'. Daphne and Harry/Hari were 'chosen' by Merrick long before the event of the rape which can be all engineered by him. Then he silenced the real rape narrative and circulated his own version of the story.

\section{IV. 'REALMS That ARE Yet TO COME'/ THE POSTMODERN}

The posthuman "is our ontology; it gives us our politics". Haraway's

$$
\text { A Cyborg Manifesto }{ }^{26}
$$

Unlike the imperialist project of subduing nature, the posthuman offers resources for the future construction of another destiny. The posthuman replaces the liberal humanist in the new multinational world order. Coomer/Kumar is one of the clearest manifests of the 'post-human', being (in)visible for both the British and Indians. Kumar is a Derridean supplement to Coomer and both become a synthesis of a Hegelian/Marxist dialectic that no one imagines his existence; thus, the author remains silent about him. He is the type that postmodern India needs. He is the hero who patiently plans his revenge from a villain who humiliated him and accused him of a crime that he did not commit. He is the one who "spoke and acted like an English boy" (TS, 378). The new much needed double identity of Hari/Harry is an essential persona who belongs spectrally into two different worlds without being truly in any one of them. He knows Merrick's homosexual tendencies, he knows about the bicycle, so he started to follows Merrick like a spectre or a ghost wherever he goes. As Bronowsky thinks, there is something Western in the Harry's scheme of revenge. After his release from prison, Harry/Hari started to link with the new generation of the Indian boys, the clean, young, educated in British-based way, those whose interests are shifted from Wordsworth and the daffodils; i.e. romantic and sentimental literature to the atomic bomb, or abstract scientific knowledge, those who were very proud to speak English fluently. Those boys took Harry/Hari as a private tutor, and this is the same kind of boys who were seen around the scene of Merrick's murder. Aziz, "who is, in all likelihood, a spy planted there by an Indian fanatic intent on avenging Merrick's actions at Mayapore", and all the Indian boys that succeeded him are young, handsome, well-disciplined, patient, witty, and hard working to attain his further aims. Most significantly, Aziz was a good reader, not only of newspapers, but of Merrick's own English books. Thus, it is quite applicable to accept the bizarre conclusion that Harry/Hari plans Merrick's murder patiently and works it out with his young Indian partnres. After his murder, Merrick was found "dressed in his Pathan clothes, ... hacked about with his own ornamental axe and strangled with his own sash" (ADS, 548). His face was smeared brown with make-up, which is an important reminder of Daphne's description of her rapists. In fact, we have a heuristic rather than hermeneutic reading of the rape because we don't have a story to rely on; thus, we collect some ghosts to flesh our phantom story, a story which is either invented or discovered, may be both.

Consequently, Kumar is 'extended' for the other/the reader who gazes at the dark side of this character, at his unconscious without knowing that he has been 'seen', 'an extension that is untouchable'. For Merrick, the Indian Kumar 'has a body, he is a body', but he is more than that. As a Western homo sapiens, he is identified with the rational mind, not the body. He is an untouchable Western extension of his Eastern Self. He knows "how to touch without touching, contact without contract". ${ }^{27} \mathrm{He}$ gains, at last, the 'impossible knowledge' of spectrally 'touching' the Western untouchable Law. Kumar/Coomer attempts 'touching' his enemy in 'absence' not in 'presence'. Thus, his signature is there in Merrick's murder. He is definitely the killer who 'reads Freud', as Bronowsky says, but he is not seen or accused.

\section{REFERENCES}

All quotations are taken from Paul Scott's The Raj Quartet (London: Arrow Books, 1966 rep. 2005). The four parts will be marked as: The Jewel in the Crown (JC); The Day of the Scorpion (DS); The Towers of Silence (TS); and A Division of the Spoils (ADS).

J.L. Austin, How to Do Things with Words (Oxford: The Clarendon Press, 1962), 12.

Jacques Derrida, Of Grammatology, trans. Gayatri Chakravorty Spivak (Baltimore: The John Hopkins University Press, 1967 rep. 1997), 23.

Jean-Francois Lyotard, The Postmodern Condition: A Report on Knowledge, trans. Geoff Bennington \& Brian Massumi (Manchester: Manchester University Press, 1979 rep. 1987), viii.

Roland Barthes, S/Z, trans. Richard Miller(Oxford: Blackwell, 1973 rep. 2002), 5 .

Radhika Mohanram, "White Sex: Rape and Race in Paul Scott's The Raj Quartet", in new literature review (nlr) (41, 2004), 65.

Jacques Derrida, "A Certain Impossible Possibility of Saying the Event", trans. Gila Walker, in Critical Inquiry $(33,2007), 441$.

Ibid., 453.

Alain Badiou, "The Event in Deleuze", trans. John Roffe, in Parrhesia (2, 2007), 41.

10Lyotard, xi.

Jean-Francois Lyotard, "Re-Writing Modernity", in SubStance (16, 1987), 4.

12Derrida, "A Certain Impossible Possibility of Saying the Event",, 445.

13Ibid., 448.

14Michel Foucault, The Archaeology of Knowledge \& The Discourse on Language, trans. A.M. Sheridan Smith (New York: Pantheon Books, 1969 rep. 1972), 130.

15Roshini Kempadoo, Creole in the Archive: Imagery, Presence and the Location of the Caribbean Figure (London: Rowman and Littlefield, 2016), 5 .

16Jacques Derrida, "The Archive Fever: A Freudian Impression," in Diacritics (25, 1995), 9.

17Richard Dyer, White (London: Routledge, 1997), 1.

18Jacques Derrida, Of Hospitality, trans. Rachel Bowlby (Stanford: Stanford University Press, 2000), 5. 
19Chela Sandoval, "Theorizing White Consciousness for a Post-Empire World: Barthes, Fanon, and the Rhetoric of Love", in Displacing Whiteness: Essays in Social and Cultural Criticism, ed. Ruth Frankenberg (Durham: Duke University Press, 1997), 87.

20Roland Barthes, Mythologies, trans. Annette Lavers (London: Vintage Books, 1957 rep. 2009), 132.

21Gilles Deleuze, Difference and Repetition, trans. Paul Patton (London: The Athlone Press, 1968 rep. 1994), 277.

22Sabina Sawhney, "The Jewels in the Crotch: The Imperial Erotic in The Raj Quartet", Sexy Bodies: The strange carnalities of feminism, ed. Elizabeth Grosz and Elspeth Probyn (London: Routledge, 1995 rep. 2002), 196.

23Allen Boyer, "Love, Sex, and History in The Raj Quartet", Modern Language Quarterly (Duke University Press), 64.

24Foucault, 5.

25Ibid., 129.

26Donna J. Haraway, A Cyborg Manifesto: Science, Technology, and Socialist-Feminism in the Late Twentieth Century (Minnesota: Minnesota University Press, 2016), 7.

27Jacques Derrida, On Touching-Jean-Luc Nancy, trans. Christine Irizarry (Stanford: Stanford University Press, 1992 rep. 2005), 7. 